\title{
Diversity of glycosil hydrolase family 18 genes in environment isolates of the entomopathogenic fungus Metarhizium anisopliae
}

\author{
Nicolau Sbaraini", Ângela Junges, Augusto Schrank \\ From 5th Congress of the Brazilian Biotechnology Society (SBBIOTEC) \\ Florianópolis, Brazil. 10-14 November 2013
}

\section{Backgound}

Metarhizium anisopliae is a model for host-pathogen studies due to its ability to infect several different arthropods. The first barrier to accomplish successful host-infection is transverse the host cuticle, which is a rigid chitin-rich structure. To surpass this barrier, the fungus produces several hydrolytic enzymes, among which are chitinases and endo- $\beta$ - $\mathrm{N}$-acetylglucosaminidases, glycosil hydrolase 18 (GH18) members [1,2]. In fungi, GH18 enzymes have nutritional importance and exhibit morphogenic and autolytic functions, acting at different processes of fungal development and life cycle maintenance. Assigning functional role for these genes in each process is one of the goals in entomopathogenic fungi study [3]. A genomic analysis performed in our laboratory, in M. anisopliae E6 strain, identified twentythree GH18 putative genes [3-5]. Considering this variety, this study aims to evaluate the diversity of these genes amongst $M$. anisopliae strains, to access their distribution in environmental isolates of the fungus. DNA samples from 23 M. anisopliae strains (CG291, NORDESTE, CARO7, CG125, CG343, CG374, CG46, CARO12, CARO14, CARO19, CG30, CG97, CG320, AL, MT, M5, CARO11, CARO15, CARO16, CG47, PL57, CG87 e CG491) isolates from different arthropods and places were subjected to PCR analysis to evaluate the presence of each of the $23 \mathrm{GH} 18$ putative genes found in the genome of strain E6.

Centro de Biotecnologia da Universidade Federal do Rio Grande do Sul (CBiot/UFRGS), Programa de Pós-graduação em Biologia Celular e Molecular (PPGBCM), Av. Bento Gonçalves, 9500, Bairro Agronomia, CEP 91501-970, Porto Alegre, Rio Grande do Sul, Brazil

\section{Results and conclusions}

From the analysis it is possible to suggest that these GH18 genes sequences are well conserved in other strains. We identified 17 M. anisopliae strains with possible absence of one or more GH18 genes. Amongst the most prominent are strains lacking five genes. ChimaA1, chimaA2, chimaA4, chimaA8, chimaB4, chimaB6, chimaD1 and chimaD2 putative genes were detected in all strains studied. Furthermore, the chimaA7 gene was not detected in eight strains and the chimaB5 gene was also not detected in six strains. Strains with the initials "CARO" from Mexico dislayed higher number of absences, compared to E6 isolated in Brazil. Geographical distance is one of the possible factors that could contribute for the divergence in these strains. Although the absence of genes in some strains does not necessarily imply ortholog absence, because the primers used in this work were constructed based on E6 strain sequences, our results suggest diversity of GH18 members amongst $M$. anisopliae isolates. The possible absence of GH18 genes may result in differences in development, morphology and pathogenicity in the fungus that are now under study. 


\section{Acknowledgements}

This work was supported by grants from CNPq (Conselho Nacional de Desenvolvimento Científico e Tecnológico, Brazil), CAPES (Coordenação de Aperfeiçoamento de Pessoal de Nível Superior, Brazil), FAPERGS (Fundação de Amparo à Pesquisa do Estado do Rio Grande do Sul) and LNCC

(Laboratório Nacional de Computação Científica).

Published: 1 October 2014

\section{References}

1. A Vainstein, $\mathrm{M} \mathrm{H}$ : Metarhizium anisopliae enzymes and toxins. Toxicon 2010, 56(7):1267-74.

2. GD Tzelepis, Melin P, Jensen DF, Stenlid J, Karlsson M: Functional analysis of glycoside hydrolase family 18 and 20 genes in Neurospora crassa. Fungal Genet Biol 2012, 49(9):717-30.

3. Junges A: Metarhizium anisopliae: Expressão de proteína toxica de origem vegetal e analise genômica de quitinases. Programa de PósGraduação em Biologia Celular e Molecular, Universidade Federal do Rio Grande do Sul 2010.

4. Karlsson M, Stenlid J: Comparative evolutionary histories of the fungal chitinase gene family reveal non-random size expansions and contractions due to adaptive natural selection. Evol Bioinform Online 2008, 4:47-60.

5. V Huemer, B Seiboth, B Kubicek, C P: A complete survey of Trichoderma chitinases reveals three distinct subgroups of family 18 chitinases. FEBS $J$ 2005, 272(22):5923-39.

doi:10.1186/1753-6561-8-S4-P111

Cite this article as: Sbaraini et al:: Diversity of glycosil hydrolase family

18 genes in environment isolates of the entomopathogenic fungus

Metarhizium anisopliae. BMC Proceedings 2014 8(Suppl 4):P111.

\section{Submit your next manuscript to BioMed Central} and take full advantage of:

- Convenient online submission

- Thorough peer review

- No space constraints or color figure charges

- Immediate publication on acceptance

- Inclusion in PubMed, CAS, Scopus and Google Scholar

- Research which is freely available for redistribution

Submit your manuscript at www.biomedcentral.com/submit
C BioMed Central 